\title{
Musealiserte relasjoner mellom liv og litteratur på Olav H. Hauge-senteret
}

\author{
Thea Aarbakke
}

Title: Musealised relations between life and work at the Olav H. Hauge Centre

\begin{abstract}
This article investigateshowone of the museums'foremost communication tools, their exhibitions, negotiates the appearance of the Norwegian poet Olav $H$. Hauge's life and literature, and the relations between them, by way of the exhibition's material components and exhibition technologies. In the exhibition, authorship and author biography intersect and meet as a unique attribute of the exhibition space. How the author's life and literature are communicated in the exhibitions and how the exhibition technologies affect the stories being told is the main focus of this analysis. Inspired by actor-network theory, the exhibition is analysed by situating museum props and exhibition technologies at the centre of the study.
\end{abstract}

Keywords: Exhibition analysis, exhibition technology, actor-network theory, exhibition design, author museum, literature, relational museology.

En av museenes fremste kommunikasjonsformer er utstillingen. Utstillingsbrosjyrer, merkelapper, glassmontre, utstillingstekster, tidslinjer, bord, vitrineskap, audioguider og touchskjermer er redskaper museene bruker for å formidle bestemte historier om originalobjekter og kopier i utstillingen, og flette dem inn i en større fortelling. Sammen konstituerer de utstillingenes kommunikasjonsverktøy. De er bragt sammen for å fortelle historier, og gjøre historiene håndgripelige.

I denne artikkelen løfter jeg frem noen av utstillingens kommunikasjonsverktøy, og ana- lyserer hvordan de påvirker fortellinger om liv og litteratur i utstillingen på Olav H. Hauge-senteret i Ulvik, på Vestlandet, i Norge. ${ }^{1}$ Det er mulig å lese Hauges diktsamling Dropar $i$ austavind (1966) uten videre kunnskap om forfatterens liv, og det er mulig å lese Knut Olav Åmås' biografi Mitt liv var draum (2004) om Hauge, uten kjennskap til Hauges diktning. I utstillingen krysser og møtes forfatterskap og forfatterbiografi. Dette er unikt for utstillingsrommet. I artikkelen undersøkes utstillingen på Hauge-senteret som en alternativ inngang til resepsjonen av Olav H. Hauge (1908-94), 
ThEA AARBAKKe

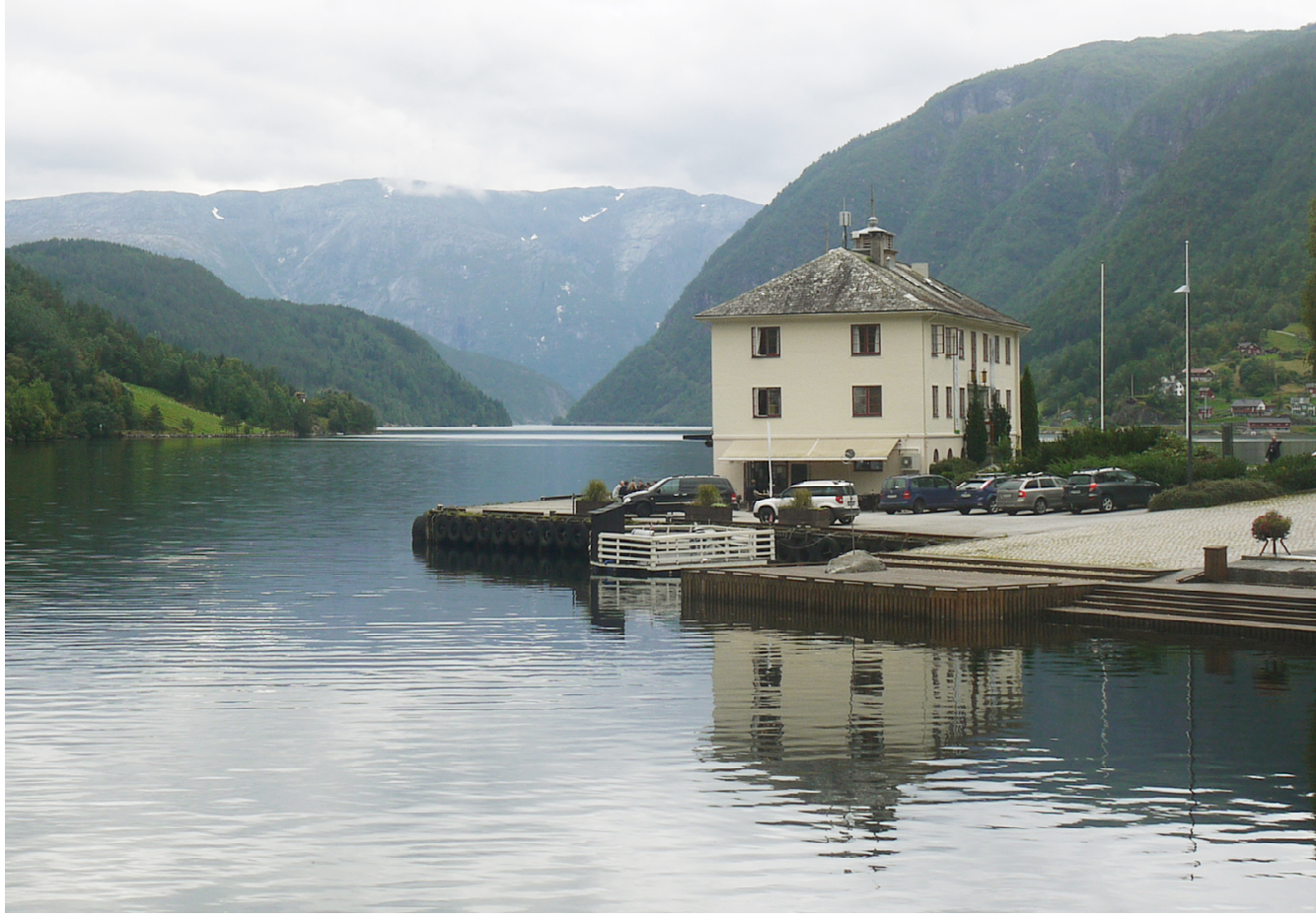

Fig 1. Hauge-senteret i Ulvik. Foto: Thea Aarbakke, 2016.

en av de viktigste dikterne i Norge fra det 20. århundret.

Hauge-senteret holder til i leide lokaler i Ulviks gamle kommunehus. Vestlandsbygden ligger langs en av fjordarmene innerst i Hardangerfjorden. I dag har bygningen utstillingslokaler, museumsbutikk, kontorlokaler og en kafé (fig. 1). Senteret åpnet i 2014 og presenterer seg som et dokumentasjons- og formidlingssenter over dikteren Olav H. Hauges liv og virke. ${ }^{2}$ I tillegg formidler senteret lyrikk i mange former på tvers av språkgrenser.

Olav H. Hauge bodde i Ulvik hele sitt liv. Der arbeidet han som fruktgartner og eplebonde. Han debuterte med diktsamlingen Glør i oska
(1946) som 38-åring. Til sammen har Hauge gitt ut syv diktsamlinger og én barnebok. Han oversatte flere diktere, blant annet Bertolt Brecht, Paul Celan og Sylvia Plath. Seks ganger ble Hauge tvangsinnlagt for psykiske plager. Hans første opphold på Valen sykehus - den gang Valen sinnsykeasyl - varte i tre og et halvt år. På 1960-tallet fikk Hauge sitt litterære gjennombrudd med diktsamlingen På Ørnetuva (1961). Han ble lagt merke til av forfatterkollegaer og kritikere i hovedstaden. I en periode var det til Ulvik diktere reiste for å bli inspirert. Det var unge, radikale diktere fra miljøet rundt tidsskriftet Profil (Kapstad 2007). I dag regnes Hauge som en av de mest folkekjære 
dikterne i Norge. I 2016 ble hans dikt "Det er den draumen" kåret til Norges beste dikt gjennom tidene av Norsk Rikskringkasting (NRK) sine lyttere og seere. Det norske slagordet på bokmessen i Frankfurt 2019 var "Der Traum in uns", direkte inspirert av Hauges dikt.

\section{UTSTILLINGSTEKNOLOGIER SOM KOMMUNIKATIVE VERKTØY}

I analysen av Hauge-senterets utstilling, har jeg valgt å fokusere på tre ulike gjenstander som befinner seg i utstillingen: to vinduer, et bord og en bokhylle. Utvalget er et resultat av et ønske om å fokusere på punkter i utstillingen hvor fortellinger om litteratur og liv møtes. I tillegg er vinduer, bord (særlig skrivebord) og bokhyller med bøker konvensjonelle, museale grep for å stille ut forfatterskap. ${ }^{3}$ I avgrensningen ligger det også en ambisjon om å utvikle en felles taksonomi for å analysere flere forfattermuseers utstillinger og sammenligne dem.

Michelle Henning har vist hvordan utstillingsteknologier setter objekter i arbeid, men også hvordan teknologiene skaper nye forbindelser mellom objektene og publikum (Henning 2006). Vinduene slipper naturlig lys inn i utstillingen, og gir utsikt til senterets omgivelser. Bordet har en flate hvor en rekke gjenstander er samlet, dets form inviterer besøkende til å samles rundt det. Bokhyllene, med låste glassdører, stiller ut og beskytter boksamlingen etter Hauge. I tillegg, har utstillingsteknologienes design og utforming en effekt som institusjonene kan bruke, og som de i flere tilfeller benytter seg av. Alle tre løfter frem og ekskluderer bestemte deler av Hauges liv og litteratur som medieres gjennom dem. Derfor er det viktig å undersøke hvilket arbeid de gjør i utstillingene, og hvordan de kommuniserer senterets fortellinger om Hauge.
For at utstillingsteknologienes arbeid skal 77 komme til syne, bruker jeg konsepter utviklet innen aktør-nettverksteori. Det teoretiske og metodologiske rammeverket præsenteres først. Utstillingsanalysen har tre deler, hvor jeg arbeider med de tre utstillingsteknologiene hver for seg. Avslutningsvis vil jeg diskutere hvorvidt utstillingsteknologienes formale, materielle og teknologiske kvaliteter har konsekvenser for fortellingene utstillingen kommuniserer.

\section{AKtør-netTVERKsteori}

Aktør-nettverksteori (ANT) er ikke et homogent, teoretisk felt. Først og fremst er ANT utviklet for vitenskapssosiologiske studier, og er plassert innenfor vitenskaps- og teknologistudier (STS). Innen museologi og museumshistorie, har aktør-nettverksteori tilbudt perspektiver som flere forskere har opplevd som nyttige. ${ }^{4}$ I boken Post-Critical Museo$\log y$, skisserer forfatterne opp et skille mellom studier av hva museer er og hva museer gjør (Dewdney et al. 2013:189). A fokusere på hva museer gjør er inspirert av aktør-nettverksteori, særlig vitenskapssosiologen Bruno Latours bok Reassembling the Social: An introduction to Actor-Network-Theory (2005). Det er et deskriptivt verktøy for å forklare hvordan relasjoner blir til.

Jeg vil trekke frem to perspektiver fra ANT, som har hatt stor betydning for artikkelens metodologiske valg. Det første er begrepet om non-humane aktører, det andre er relasjonell materialitet. En aktør defineres og forstås som noe eller noen som gjør noe. En aktør handler og skaper endring (Mol 2010). At et bord eller en bokhylle får aktørstatus, høres mer kontroversielt ut enn det i realiteten er. Det betyr ikke at gjenstandene tilegnes bevissthet, eller egenvilje. Det betyr at vinduet, bordet og bokhyllen blir behandlet som noe mer enn passive over- 
flater og beholdere i analysene. En utstillingsplan, bestående av tekst og plansjer, er noe annet enn utstillingsplanens resultat, $i$ form av en utstilling. Aktør-nettverksteori utfordrer idéen om at det står enkeltstående subjekter bak praksiser. Poenget er at flere elementer og aktører er involvert (Damsholt \& Simonsen 2014/2009:13). I nettverksteori tar virkeligheten form som et resultat av relasjoner mellom elementer. Relasjonene inkluderer både mennesker og gjenstander. Sosiologen John Law kaller det relasjonell materialitet (Law 1999). Ting oppstår ikke i et vakuum, men i relasjon til hverandre. Det handler ikke først og fremst om tingene i seg selv. Det handler om hvordan tingene inngår i sosio-materielle prosesser og praksiser. Materialitet forstås som noe som eksisterer i kraft av deres relasjon til andre fenomener (Damsholt \& Simonsen 2014/2009).

Ifølge Hauge-senterets utstillingsplan, skal utstillingen være selvforklarende (Hauge-senteret 2013:13). Senteret tilbyr omvisninger, men utstillingen er bygget opp slik at publikum skal kunne oppleve den, og lære noe av den, på egenhånd. Det betyr at menneskene som står bak utstillingskonsept og -design, har delegert informasjonsarbeidet til tingene. I analysen vil jeg vise til utstillingsdokumentet, for å diskutere formålet med bestemte utstillingsgrep. Gjenstandene får også aktørstatus, og jeg undersøker hvordan deres materielle egenskaper, plassering og formale trekk påvirker det som blir kommunisert i utstillingen. $\AA$ forklare hvordan noe står i relasjon til noe annet, gir andre svar enn å forklare noe som et tegn for en annen, bakenforliggende mening. Å etablere en forbindelse mellom to ting, er noe annet enn å forstå noe som substitutt for noe annet (Latour 2005:100). A tolke en gjenstand som et symbol for en bakenforliggende mening, fører analysen andre veier enn å tolke gjenstanders mening gjennom relasjoner. Per- spektivet hjelper meg å se de selvfølgeliggjorte utstillingsteknologiene med et nytt blikk.

\section{Metode}

Jeg gjennomførte etnologisk feltarbeid på Hauge-senteret over to perioder, hovedsakelig med deltakende observasjon som metode. Første gang jeg besøkte Hauge-senteret var i september 2016 under Ulvik poesifestival, som Hauge-senteret er festivalarrangører for. Da jeg var tilbake i Ulvik våren 2018, fikk jeg en omvisning i Ulvik av en av Hauges etterkommere. Han pekte ut steder og bygninger $\mathrm{i}$ bygden som hadde hatt betydning for Hauge da han levde. I analysen av vinduene i utstillingen, viser jeg hvordan informasjonen jeg fikk om bygden fikk konsekvenser for tolkningen av utstillingen. Først og fremst oppholdt jeg meg i Hauge-senterets utstillingslokaler. Det er Hauge-senteret og Ulvik som utgjør navet for undersøkelsen. Jeg utvider utstillingsanalysen til å inkludere mer enn det som finnes innenfor museumsveggene, fordi jeg følger forbindelsene til omverden som er kuratert inn i utstillingen.

På senteret fikk jeg omvisning av den dokumentasjonsansvarlige, og jeg observerte publikum i utstillingen. Jeg var også en deltakende observatør når jeg beveget meg rundt i utstillingslokalene. Det vi gjør er ikke alltid formulert i ord, skriver etnologene Oscar Pripp og Magnus Öhlander, når de trekker frem fordelene til observasjon som metode (Pripp \& Öhlander 2011/1999:115). For å undersøke gjenstandenes aktørstatus ble observasjon en viktig metode. Deltakende observasjon var vesentlig for å undersøke utstillingens uskrevne virkninger. Å være i utstillingsrommene, bruke den, og observere andres bruk av den, sto sentralt. I tillegg dokumenterte jeg utstillingen ved å fotografere, lage skisser og notere. Me- 
toden er inkluderende og omstendelig. Tilsynelatende små ting får store konsekvenser, som plasseringen av bestemte gjenstander på bordflater og i skuffer. I tillegg synliggjør metoden utstillingens materialitet. Jeg er situert som den observerende forsker-på-museum, hvor utstillingen oppleves og analyseres i utstillingsrommene.

\section{VINDUENE}

Indre syn og ytre blikk, står det på en sponplate med påtrykkede skyformasjoner på veien inn til Hauge-senterets utstilling i første etasje. Verden utenfor kommer til syne gjennom tretten vinduer i basisutstillingen, fordelt mellom tre utstillingsrom i 1. etasje og to utstillingsrom i 2. etasje. Vinduene er doble og inndelt i seks like, kvadratiske deler av sprosser malt i hvitt. Kortsiden mot sør, og de første vinduene på sørøstveggen, peker ut mot fjorden og verden utenfor Ulvik. Fra de tre resterende vinduene på langsiden av huset ser vi bygden Ulvik med gårder og frukthager, beskyttet av fiell og åser.

Vinduene er dermed en stor del av utstillingsopplevelsen som utspiller seg på relativt små fysiske flater. Etter å ha gått gjennom rommene har landskapet utenfor også blitt en del av opplevelsen på Hauge-senteret. I utstillingen undersøker jeg diverse installasjoner. Jeg åpner skuffer og trykker på knapper, lytter til Hauges diktopplesning og går langs bokhyller med bøker fra hans private samling. I tillegg har fjorden utenfor - fruktgårdene, bebyggelsen, fjellene og været som kan ses gjennom de tretten vinduene - omsluttet tekstene og bildene jeg leser og observerer på plansjer, trykk og annet utstillingsdesign i rommene. I tillegg til å la omgivelsene få være en del av utstillingsrommene, setter vinduene landskapet utenfor på utstilling. Dette er et bevisst grep fra senteret. I senterets utstillingsplan står det:
Utsynet frå Hauge-senteret sine mange vindauga 79 er om lag det same panorama som Hauge hadde frå huset sitt. Til å få fram konteksten i landskapet utanfor Hauge-senteret kan vi i vindauga bruke den teknologien frå bilindustrien som gjer at informasjon kjem opp på glasfelt (Hauge-senteret 2013:19).

Senteret tar i bruk vinduene for å få frem en relasjon mellom landskapet utenfor, og det Hauge observerte fra huset sitt. Hvilke fortellinger presenteres i vindusruten, og hvordan er vinduenes formale og materielle trekk med på å forme disse fortellingene?

Midt på høyre side av det første vinduet i utstillingsrommet i 1. etasje er det montert en ramme i tre. Den brede trerammen gjør at den fungerer som en slags titteboks, bortsett fra at bunnen er borte. Innrammingen styrer blikket på en bestemt måte, ut istedenfor inn, men først og fremst på ruten fordi kurateringen får frem rutens to-dimensjonale form som flate. Innenfor rammen er det festet en gjennomsiktig stensil med et dagboksnotat fra Hauge, datert 10. oktober 1959, da Hauge var 51 år. Sitatet er skrevet både i original språkform og i engelsk oversettelse. Nynorsk og engelsk er de gjennomgående språkformene i utstillingen. Teksten tar litt under halvparten av vinduets overflate som rammes inn av boksen. Resten av overflaten innenfor boksen er ikke dekket til slik at vi kan se landskapet utenfor gjennom den (fig. 2). På stensilen står det:

\section{Onen}

Vassfjøro, Onen, Hårteigen, Oksen, dei stend der kvar for seg,

Grimute og verbitne og veit

um kvarandre, i allefall

når turisten er reist!

Dagbok, 10. oktober 1959. 


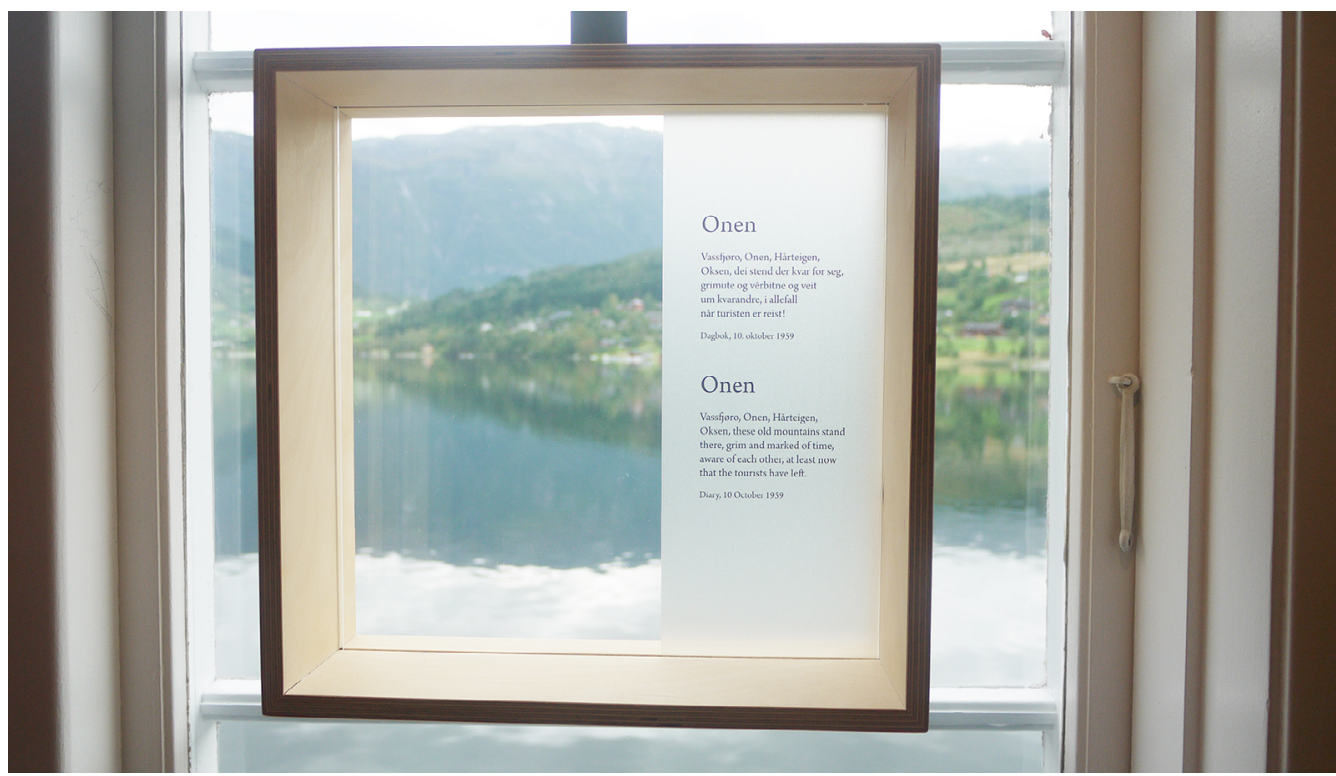

Fig. 2. Et av seks vinduer i utstillingen med tekst på Hauge-senteret. Foto: Thea Aarbakke, 2016.

Etter å ha lest teksten skifter fokuset og blikket vendes ut mot det som rammes inn av boksen. På feltarbeid på Hauge-senteret i 2016 så jeg den karakteristiske vestlandsnaturen: høye fjell speilte seg i vannet og dannet et kontrastfylt landskap gjennom innrammingen. Tilbake på senteret i 2018, etter at Hauges slektninger hadde gitt meg en omvisning i bygden, så jeg Vassføøro, Onen, Hårteigen og Oksen, som er navnene på fjellene som omkranser den vesle bygden, og kan ses gjennom dette vinduet. I kurateringen gjøres vinduet til et omdreiningspunkt for å kople utstillingsrommet til landskapet utenfor ved å benytte to av vinduets egenskaper, nemlig dets transparente overflate, og vinduets mulighet til å ramme inn et bestemt utsnitt. I teksten på vindusflaten kommer dagbokskriveren Hauge frem. Når senteret velger et sitat som nevner lokale stedsnavn viser de en forbindelse mellom Hau- ges dagboksnotater og stedet han bodde, som også er der utstillingen står. Forbindelsene vinduene skaper mellom det Hauge skrev, det fysiske landskapet og stedet jeg står, skaper en forståelse av at dette stedet var viktig for Hauges tanker og skriving. Teksten på ruten gir landskapet og omgivelsene en bestemt litterær mening. Leseren som teksten adresseres til er først og fremst det lokalkjente publikum. Ikke nødvendigvis dem som er kjent med Hauges dikt, men til dem som kan avlese den stedlige referansen i tekstutdraget og innrammingen av omgivelsene på vindusflaten.

Til sammen er det seks trerammer i utstillingen, de er montert på hvert sitt vindu. Hver av dem har en stensil med et tekstutdrag festet på ruten. Jeg vil her presentere en til, for å analysere en annen utsikt, nemlig den som vender ut mot fjorden. Her står et utdrag fra en skolestil Hauge skrev som sekstenåring, i 1924. 


\section{Utferdshug}

Men so kanskje, helst i store stunder, baarar ein sterkare trong gjennom meg; utferdshugen. Ut i den vide verdi og sjaa meg ikring, sjaa alt eg hev høyrt og lest um. Burt i den nye Verdi og sjaa, og vera med paa livet der paa dei store viddone, eller i dei store myrke skogane.

\section{Skulestil, 1924.}

Blikket ledes ut av Ulvik til utsikten bak ruten. Fjellene møtes i en V-form før de går ned i sjøen og horisonten virker uendelig. Ordene $i$ skolestilen viser en annen Hauge enn han vi ble presentert for i det forrige tekstutdraget. Først presenteres vi for den bofaste Hauge, deretter for han som vil bort fra Ulvik og ut i verden. Dette motsetningsforholdet skaper en dynamikk mellom han som ble, og han som kanskje $ø$ nsket seg ut i verden. Motsetningsforholdet resonnerer også i utstillingens tittel, Indre syn og ytre blikk. Vindusglassets materielle kvaliteter skaper utsikter, men ikke alltid en fokusert utsikt. Det gjør at man kan se på andre måter, der det som befinner seg utenfor utstillingsrommet ikke er det viktigste i formidlingen, men hvordan vinduet også muliggjør kontemplasjon. Til forskjell fra teksten om "Onen", som rammes inn av trerammen og fysisk kan lokaliseres på andre siden av fjorden med et bekreftende pek om at der er fjellet, peker ikke teksten "Utferdshug" på ett fiksert punkt. Det får frem den drømmende egenskapen som vinduenes transparente overflate skaper. Blikket vendes innover, til et slags indre liv, og ikke nødvendigvis til turisten som er på besøk, eller eventyreren som skal ut. Teksten i skolestilen underbygger denne drømmende egenskapen som vinduet får frem. Siden det ikke er et konkret sted "der ute" som rammes inn, gjøres verden utenfor Ulvik først og fremst til noe annet, uten at det er synlig for oss.

Hvilken form for oppmerksomhet produserer de kuratoriske grepene på vinduenes overflater? De trekker landskapet utenfor inn i utstillingsrommene og skaper bestemte forbindelser mellom Hauge og den lokale naturen. I utstillingen påvirker vinduenes materielle kvaliteter fortolkningen av tekstene, som er montert på vindusruten. I utstillingen forteller tekstene om dikteren som ble, som i skolestilen fra tenårene drømte om å reise ut, men som skriver dagboksnotater om nærmiljøet og landskapet i Ulvik. Å bruke omgivelsene i utstillingen kan skape tilhørighet mellom dikter og museumslokasjon, men også redusere lyrikeren til et sted. Andre steder i utstillingen kommer det frem at "utferdshugen" ikke kan begrenses til ungdomsårene, og som jeg vil vise skaper utstillingen også andre versjoner av Hauge, om han som reiste og som studerte andre steder. En vindusrute har andre kvaliteter ved seg enn for eksempel et bord. Deres materialitet og måter publikum kan samhandle med dem på, påvirker hvilke fortellinger hvert enkelt medium kan formidle i utstillingene.

\section{BORDET}

Midt i det største utstillingsrommet i 1. etasje står det et bord (fig. 3). Dets formale trekk gjør at det minner om et spisebord i både høyde og størrelse, men bordet på Hauge-senteret er ikke dekket til middagsselskap. På bordplaten er det en botanikkbok, sidene er limt over med avisutklipp av diverse dikt. Til høyre for utklippsboken ligger et fotografi av en ung mann sittende i en robåt, en enveis togbillett fra Voss til Oslo datert og to kaffekopper. Alle disse gjenstandene er enten kopier eller rekvisitter. 
ThEA AARBAKKe

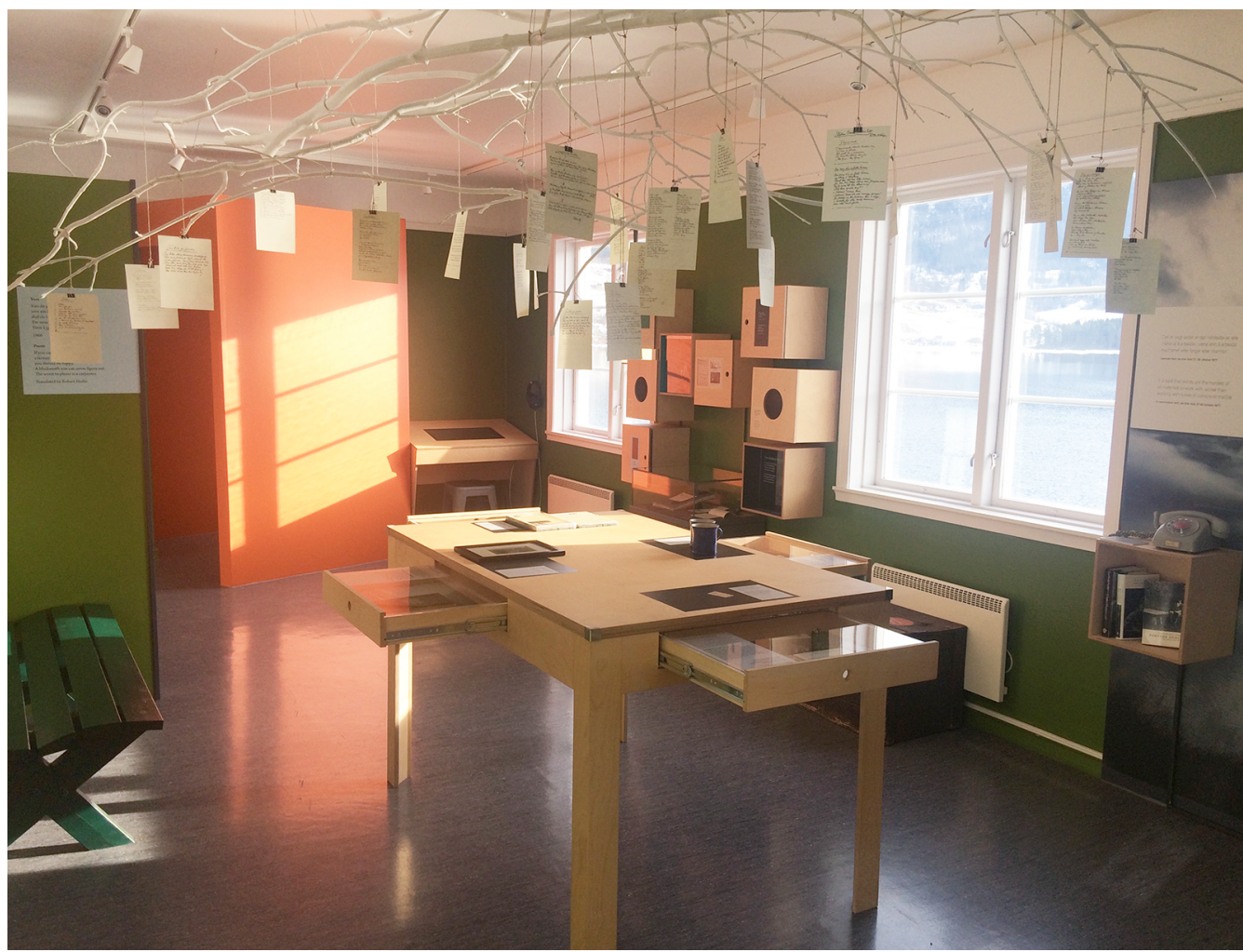

Fig. 3. Bordet i utstillingen på Hauge-senteret. Foto: Thea Aarbakke, 2018.

Utstillingstekster, plassert ved siden av gjenstandene, beskriver gjenstandenes forbindelser til Hauges liv og litteratur. Alle utstillingstekstene er sitater hentet fra Hauges dagbok. Slik kurateres Hauges tanker, meninger og ord inn i bordet. Ved siden av utklippsboken er det plassert et dagboksitat fra 1929. Der står det at Hauge har begynt å studere på hagebruksskole og at han nå må "leggja både litteraturen og språki på hylla. Um ei tid hev eg vel gløymt alt i hopa." Ved siden av fotografiet, med motiv av en smilende Hauge i en robåt, er det et annet utdrag fra dagboken, datert til 1937. Der står det at Hauge er lei seg for at faren ikke kan ha ham hjemme. Hvorfor han ikke kan være hjemme er uvisst ut fra fotografiet, dette vil jeg komme tilbake til. Ved siden av togbilletten står det at Hauge har pakket og forberedt en reise til Oslo neste dag. Ved siden av kaffekoppene står et sitat fra 1944 om at mennesker først er lykkelige i samspill. På Hauge-senteret kan publikum samles rundt alle fire sidene av bordet for å betrakte utstillingen, bla i utklippsboken og lese tekstene. Dets overflate gir oppmerksomhet til disse gjenstandene og fortellingene om dem. Dagboksitatene gjør kopien av utklippsboken, og fotografiet, togbilletten og kaffekoppene til Hauges eiendeler. Sammen beskriver de personen Hauge som studerte, men samlet på dikt, han som måtte flytte hjemmefra, han som rei- 
ste og om han som ønsket å leve sammen med en annen. Utstillingstekstene som koples til gjenstandene forteller om han som dro, ikke om han som ble. Dikteren Hauge er tilstede i bordets overflate gjennom utklippsboken. De andre gjenstandene er hverdagslige, og forteller mer om hans hverdagsliv enn virke.

Bordet har fire skuffer som kan åpnes. Det gir bordet et nytt lag med informasjon, som publikum har tilgang til hvis de interagerer med det. Fokuset skifter fra overflate til innhold. Bordets tredimensjonale form aktiveres når skuffer dras ut og innholdet utforskes. Skuffene skaper også et nytt nivå i utstillingen: mens overflaten er synlig for alle er fortellingene i skuffene kun synlig for dem som finner dem og åpner dem.

I skuffene er det stilt ut brev, anmeldelser, intervjuer og fotografier som bidrar til å skape forbindelser mellom gjenstandene på bordet, skuffenes innhold og verden utenfor, mellom Hauge som privatperson og Hauge som forfatter. Når flere fortellinger trer frem i skuffene, får gjenstandene på bordoverflaten nye meninger. Togbilletten og teksten på bordet ga inntrykk av Hauge som den reisende, han som pakker kofferten og tar toget til Oslo. I skuffen under står det at da han ble tildelt Norsk kritikerforenings pris i 1961, reiste han ikke til Oslo for å motta den. Videre står det at han senere begynte å reise mer, og at han tok del i det litterære miljøet rundt tidsskriftet Profil.

I skuffen under utklippsboken med dikt står det om Hauges dikterdebut, men at det kostet ham dyrt fordi han kort tid etterpå ble innlagt på sykehus. I skuffen under fotografiet ligger det en sykehusjournal, og en tekst om tvangsinnleggelsen hans på Valen sykehus. I Hauges tid var Valen det største sinnsykeasylet på Vestlandet, skriver Åmås i biografien om Hauge. Hauge fikk diagnosen schizofreni, men Åmås påpeker at diagnosen den gang ikke var den samme som den er i dag. Det som er sikkert var at Hauge i perioder var manisk og hadde vrangforestillinger (Åmås 2004:89). At sykehusjournalen er gjemt forsterker objektets status som et vanskelig objekt, og i ytterste fall til noe skambelagt. En skuff er kanskje et vanlig sted å oppbevare en slik gjenstand i et hjem, men hvorfor ikke plassere utklippsboken i skuffen, og sykehusjournalen på bordet? Utklippsboken er en materialisering av den unge gartnerstudenten som drømte om å være dikter. Mens utstillingstekstene skaper forbindelser mellom Hauges arbeid med diktsamlinger og sykehusinnleggelsene, blir plasseringen av journalen i en skuff del av en slags skjult sykdomshistorie. Sykehusjournalen er plassert under fotografiet av en ung Hauge og sitatet fra Hauges dagbok der det står at faren hans ikke kan ha ham hjemme. Skuffens innhold gir sitatet om faren en ny mening, knyttet til sykehusopphold og psykisk lidelse.

Hauges slekt er representert i sitatet hvor faren hans nevnes, uten at den samme inkluderende forbindelsen skapes mellom Hauge og faren som den som kommer frem i presentasjonen av Hauges relasjon til Profil-kretsen. Den siste skuffen får frem en annen viktig relasjon i Hauges liv. Under de to krusene ligger det første brevet som tekstilkunstneren Bodil Cappelen, senere Hauges kone, skrev til ham, datert 23. februar 1970. Hun flyttet til Ulvik og ble samboer med Hauge i 1975, da var Hauge 67 år gammel. Skuffene tematiserer dikterdebut, psykisk sammenbrudd, gjennombrudd som forfatter og gjennombrudd som menneske.

Bordet skal ikke bare betraktes, men også håndteres om besøkende vil oppleve dets fulle potensiale. Det rektangulære bordet endrer form når skuffene dras ut, fra overflate til beholder. Slik kan bordet forstås ut fra to nivåer: enten på overflaten, hvor historier om 
gartneren som drømmer om å bli dikter og den reisende fortelles gjennom utklippsboken og togbilletten. Eller ved å gå nærmere og interagere med bordet og dermed få innsyn til skuffenes innhold. Under overflaten koples forbindelser mellom Hauges diktning og Hauges psykiske plager sammen i en kausal forklaring. I arbeidet med diktsamlingene førte overanstrengelser og arbeid til innleggelse, er bordets fortelling. Når denne forbindelsen kommer til syne i skuffen, og ikke på bordets overflate, skaper bordets fysiske utforminger også assosiasjoner til et indre liv, fortalt i skuffene.

En del av Hauge-resepsjonen er at han som menneske var en tilbaketrukket mann, som bodde sammen med foreldrene sine og til dels alene på gården sin i Ulvik før han som syttiåring giftet seg med Cappelen (Åmås 2004). På grunn av sykdom var han isolert fra omverden i perioder av livet. I tillegg var sykdommen stigmatiserende. Det førte til at det var vanskelig å sosialisere seg i bygden etter lange sykdomsopphold. Bordet i hovedutstillingen på Hauge-senteret fokuserer på samlivet med Cappelen, togbilletten skaper forbindelser til reisevirksomhet og fotografiet er fra studietiden. Alle objektene er knyttet til steder eller personer utenfor hjemmet. Installasjonens objekter, og forbindelsene mellom dem, forteller en annen historie enn den om den ensomme kunstneren. Bordet, gjenstandene på det og skuffene får frem forbindelsene Hauge hadde med omverdenen, både steder, mennesker og reiser. Vinduet hvor teksten "Onen" er kuratert skaper forbindelser mellom Hauge og Ulvik som hjemsted. I bordet forstås ikke Hauge ut fra stedet Ulvik, naturen der og det som foregikk i umiddelbar nærhet. Bordet, og hvordan gjenstandene er plassert på og i det, forteller andre historier om Hauges liv og litteratur. Dette handler ikke bare om tekstenes meningsinnhold, men hvordan gjenstandene gjøres meningsbærende på en bordoverflate og plassert i skuffer, i relasjon til dagboksitatene.

\section{BOKHYLLEN}

Bøkene er den største samlingen Hauge-senteret forvalter av tidligere eiendeler etter forfatteren. Boksamlingen utgjør omtrent 83 hyllemeter, og er på over 6200 eksemplarer. Om lag 60 prosent av samlingen står i utstillingslokalene, de resterende 40 prosentene er lagret i senterets magasin. Den utstilte delen står i senterets 2. etasje. Langs veggene, gjennom to rom står boksamlingen inntil vestveggen, i hyller bak glassdører med lås (fig. 4). Foran bokskapene er det plass for publikum til å bevege seg.

Organiseringen av bøkene bak glassdører minner om en utstillingspraksis som presenterer gjenstandsmagasiner for publikum. Utstillingspraksisen viser frem senterets back stage og senterets samling. Samlingene er museenes råmateriale og ressurs (Bouquet 2012:141). Boksamlingen presenteres som senterets ypperste eiendel og forskningsobjekt, og viser frem senterets relevans som en aktør i Hauge-forskningen. Gjennom glassdørene vises en del av senteret "bak scenen" frem. Samtidig skiller glassdørene med lås publikum fra museumsansatte og forskere, og skaper en grense mellom besøkende og museumsansatte gjennom sansene: publikum kan se, men ikke røre. Religionsviteren Steph Berns har studert hvordan glassmontre gjør noe med innholdet de rommer, og hvordan besøkende interagerer med dem. Glassmontrene fungerer som en beskytter, som har overtatt museumsvaktens overvåkende rolle og ansvar for å hindre besøkende i å berøre utstillingens mest kostbare og skjøre gjenstander (Berns 2016). Det er den dokumentasjonsansvarlige som er portvokter og døråpner til boksamlingen, som holdes luk- 
Musealiserte Relasjoner mellom liv og litteratur PÅ Olav H. HAUge-SENTERet

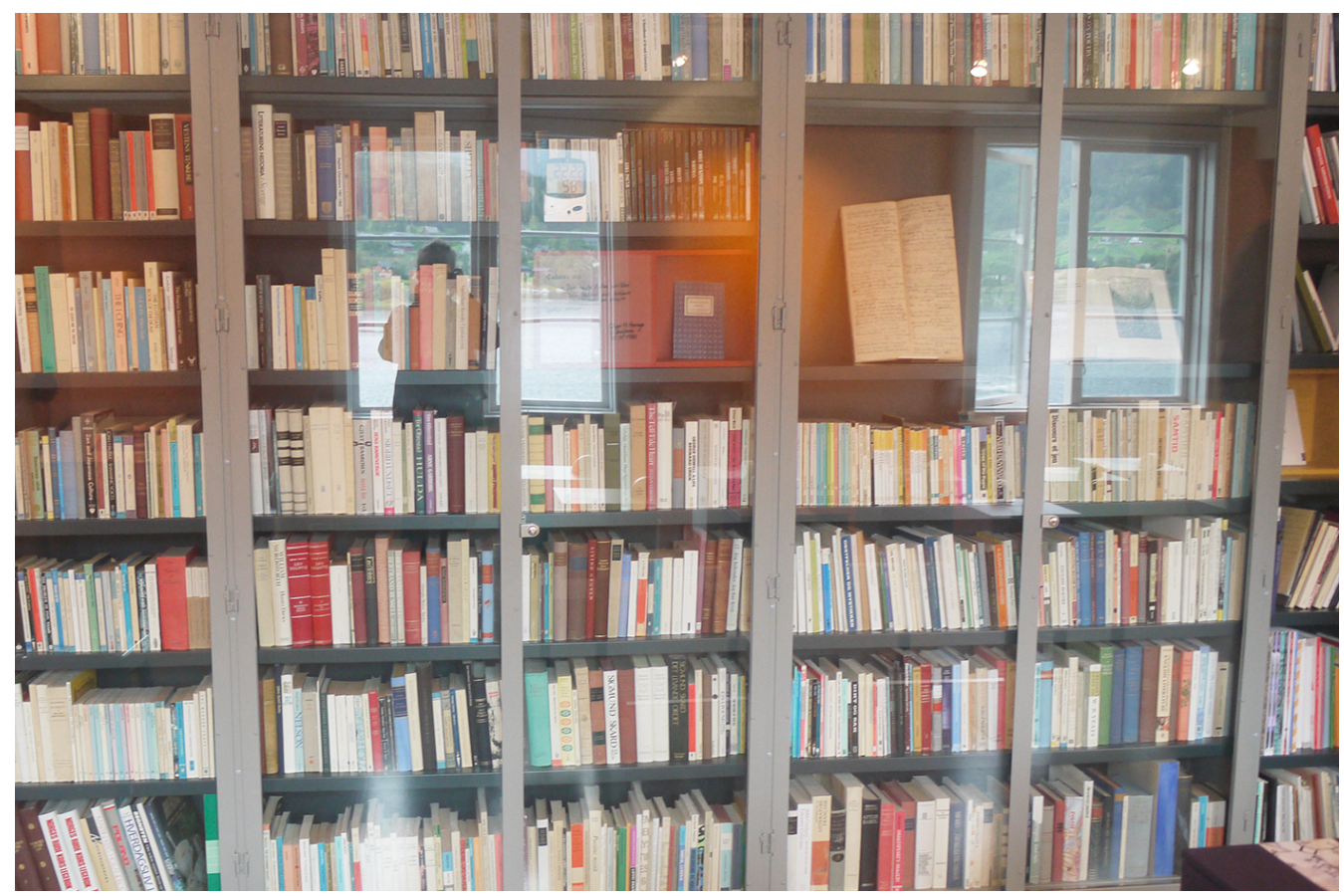

Fig. 4. Olav H. Hauges boksamling, Hauge-senteret. Foto: Thea Aarbakke, 2016.

ket og låst for publikum. Bøkenes innhold er først og fremst tilgjengelig for forskere og senterets ansatte. Likevel er ikke samlingen gjemt i magasiner, men på utstilling. Bøkene har en fortelling som samling, som senteret formidler til sine besøkende.

Bokskapene er plassert langs veggene $\mathrm{i}$ to åpne rom, dermed har besøkende god anledning til å komme tett på bøkene, lese bokryggene, studere titler og forfattere. Bokhyllene inviterer besøkende til en organisert form for gange foran hyllemeterne, på grunn av de tettpakkede bokryggene. Jeg vil sammenligne møtet med den utstilte boksamlingen på Hauge-senteret, med å kikke gjennom bokhyllene på første besøk i andres hjem. Det er en måte å gjøre seg kjent med et annet menneske på, ved å studere preferanser, smak og valg av lit- teratur. Fordi bokskapene er låst er det ikke mulig for en vanlig besøkende å undersøke hvorvidt Hauge leste bøkene som ses gjennom glassdørene. Uansett, åpner møtet med hyller, bokrygger og glassdører opp for en refleksjon rundt Hauge som leser. Denne formen for interaksjon med boksamlingen henvender seg først og fremst til dem som selv kommer fra et hjem fylt med bøker. Med e-bøker og lydbøker har også bokhyllen forsvunnet fra manges stuer. Yngre publikummere har ikke nødvendigvis den samme gjenkjennelige opplevelsen av denne formen for å presentere bøker, eller de vil ha andre assosiasjoner, til skolebibliotek og til bokhandler.

I bokhyllen på Hauge-senteret støter jeg på gjenkjennelige bøker fra bokhyllen hjemmefra. Det er også overraskelser, eller bøker som 
føles personlige og nærmest private. For meg var det spesielt å komme over en biografi om Sigrid Undset i samlingen til Hauge, fordi jeg selv har vært interessert i Undset som person og forfatter. Hadde også Hauge vært interessert i Undsets liv? Jeg hadde ikke muligheten til å åpne boken bak glassdørene, så om den inneholdt understrekninger, Hauges signatur, eselører, kaffeflekker eller andre tegn på at den var blitt lest var ikke mulig å vite gjennom dette møtet. Ut fra mine egne litterære preferanser skaptes det en kopling mellom de to forfatterne foran glassdøren, en assosiasjon som sier mer om mine interesser enn Hauges. Uansett viser denne koplingen hvor virkningsfull bokhyllen kan være for en besøkende, som går langs hyllene og studerer titlene.

Nederst langs gulvet står bøker om kinesisk lyrikk. Med kunnskap om Hauges dikt "Til Li Po" fra På Ørnetuva (1961), og "T’ao Ch’ien" fra Spør vinden (1971) er dette en spesielt spennende del av Hauges boksamling å kunne studere. Den styrker forbindelsen mellom Hauge som dikter og Hauge som leser, og kjernen til Hauges inspirasjon. I begge diktene er Hauge tydelig på sine inspirasjonskilder. I diktene refererer han til hvilke forfattere han leser og er i dialog med. Bøkenes plassering er et resultat av at den presenteres etter Hauges eget system, fra hans bokhyller på gården Rossvoll. Rekkefølgen har fått forrang fremfor mer tilgjengelige hyller lenger oppe på veggen. Samlingen av kinesisk lyrikk er kanskje mindre tilgjengelig på Hauge-senteret enn slik de sto plassert da Hauge selv brukte dem.

Jeg finner også titler som oppleves mer private. Sex for voksne er et eksempel på at boksamlingen er et tverrsnitt av den private og den offentlige Hauge, og denne boken gir assosiasjoner til førstnevnte. Vi kikker inn i den uredigerte, private boksamlingen som inneholder mer enn litterære referanser til Hauges eget arbeid. Boken viser frem hans privatliv, Hauge som menneske, kjønn og ektemann. Eksemplaret viser også autentisiteten til boksamlingen, fordi den gir inntrykk av at samlingen ikke er sensurert eller redigert av senteret. Bøkene i bokhyllen veksler mellom å gi assosiasjoner mellom dikteren Hauge, og mennesket Hauge.

$\AA$ assosiere boktitlene til Hauges liv og forfatterskap gjør det til en nær og personlig utstillingsopplevelse. Alle disse bøkene virker på meg, og skaper assosiasjoner og koplinger til ting jeg selv har lest og hørt om, og koplinger mellom Hauge og andre forfattere. Andre besøkende vil ha andre assosiasjoner og skape andre forbindelser; poenget er at den skaper forbindelser.

Bokhyllene skaper også distanse. Glassdører og lås begrenser interaksjonen med bøkene til bokryggenes og smussomslagenes assosiasjonslek. For å åpne opp samlingen på andre måter har senteret kuratert inn små tekstutdrag. Innimellom hyllemeterne er det gjort plass til fire bokser hvor tekstblokker er plassert inn i bokhyllene. Sitatene er også her hentet fra Hauges dagbok. De fire mellomrommene med presentasjon av tekst gjør at kurateringen av boksamlingen tydeliggjøres. Selv om bøkene er stilt ut i bokhyller, som er en konvensjonell og naturalisert presentasjon av en boksamling, gir de fire boksene med tekstutdrag ekstra oppmerksomhet til bestemte deler av samlingen. I dem blir andre, utenforstående aktører presentert. De skaper nye forbindelser, som ikke bokryggene alene kan kommunisere.

Sitatene er skrevet for hånd, i en skrivestil som ikke likner Hauges. De er markert med anførselstegn og kildehenvisning. Det er tydelig at det er Hauges egne ord som formidles, redigert og kuratert av senteret. I et av sitatene står det: 
NOVALIS

Denne merkjelege mannen har sagt

ymist som er vitugt, som peikar

framyver til seinare diktning.

Hugo Friedrich meiner det.

Olav H. Hauge i dagbok, Pinsedag 1968.

Formen sitatet har fått $\mathrm{i}$ utstillingen er gjengitt her, men det er ikke slik det står skrevet i den trykte utgaven av Dagbok, Olav H. Hauge band III (2000), eller i notatboken til Hauge, slik han skrev det med penn i løkkeskrift 2. juni 1968. ${ }^{5}$ I utstillingen er det skrevet i verselinjer, som et dikt. Hauge har blitt kalt hverdagsdikter og hverdagsfilosof, og mange av diktene hans er inspirert av hverdagslige betraktninger. Måten senteret presenterer dagboksitatet, gir dermed også assosiasjoner til hans diktning. At sitatet er hentet fra Hauges dagbok, peker på at hans egne dagbokskildringer er en kilde til informasjon om boksamlingen. Det viser hvordan han brukte dagboken, tanker han gjorde seg om bøkene, og om forfatterne han leste. I sitatet nevnes to navn, Novalis og Hugo Friedrich. Novalis er pseudonymet til den tyske poeten Friedrich Leopold von Hardenberg (17721801), og Hugo Friedrich (1904-78) var en tysk litteraturviter. Jeg finner bøker av begge forfatterne i bokhyllen på Hauge-senteret. Sitatet kopler sammen enkeltbøker fra Hauges boksamling. Sitatene plassert i bokhyllen får frem dagbøkenes potensial som kilde og synliggjør forbindelser mellom leseren og tenkeren Hauge, og potensielt dikteren. De får frem hvordan Hauges dagbok og boksamling kan være kilder til kunnskap om hans inspirasjon og lesevaner, og hvordan han forholdt seg til verdenslitteraturen. Gjennom glassdørene er det ikke mulig å vite hvorvidt samlingen er lest, men Hauges eierskap styrkes gjennom de utvalgte sitatene som står skrevet mellom bøkene i hyllene. De viser at Hauge ikke bare var en bibliofil samler, men en leser.

Boksamlingen er utstilt ved siden av utstillingen Lyrikkbiblioteket. Lyrikkbiblioteket tematiserer ulike former for poesi, blant andre haiku, joik og Håvamål. Den er en del av utstillingen som fokuserer på lyrikk i mange former. Konteksten bidrar til å viske ut grensene og forskjellene mellom vestlig poesi og resten av verden. Forbindelser, inspirasjon, sammenhenger og grenseoverskridelser gjøres til de bærende poengene.

I det kjente essayet Forfatterens død (1967) analyserer semiotikeren Roland Barthes hvordan litteraturen består av flere - i første omgang ugjenkjennelige - stemmer som ikke kan skjelnes fra hverandre ved første gjennomlesning. Barthes dekonstruerte teksten for å stille spørsmål ved et forfatterskap, og argumenterte for at teksten er en vev av flere forfattere. "Hvem snakker?" spør han, og dekonstruerer videre i essayet hvordan litteraturen består av flere stemmer, og ikke først og fremst skal forstås ut fra en forfatter (Barthes 1994:52). Metoden Barthes foreslår, og som gjøres tilgjengelig i den kuraterte versjonen av Hauges boksamling, er å kunne følge teksten til forfatteren som å nøste opp en trådsnelle, ved å følge dens stadier, og ikke hoppe over elementer for å peke på en bakenforliggende mening. I denne metoden blir Hauges biografiske liv sekundært i relasjon til litteraturen. Andre kilder, som lesning og språk, blir sporene å følge. Den utstilte boksamlingen på Hauge-senteret synliggjør litteraturens flerstemthet. Boksamlingen viser hvilke bøker Hauge leste, hvordan han tenkte over det han leste og hvilke forfattere og bøker som opptok ham. Slik plasserer Hauge-senteret boksamlingen inn i delen av utstillingen viet til verdenslyrikken, som et punkt i et større nettverk, hvor også Hauges diktning 
settes i sammenheng til forfatterne som inspirerte ham. Boksamlingen skaper forbindelser mellom Hauge og omverden, og hvordan han fikk verden hjem til Ulvik, gjennom litteraturen. Bokhyllen er så rik på titler og forfattere at mange besøkende vil finne gjenkjennelige verk. Boksamlingen skaper forbindelser mellom besøkende, og bøkene i bokhyllen, og videre til Hauge, nettopp fordi Hauge som leser er lettere for flere å kjenne seg selv igjen i, enn Hauge som dikter.

\section{Diskusjon Og AVSLUtTENDE KOMMENTARER}

Museer viet til én kunstner eller forfatter har ofte et sterkt personfokus. Mennesket og liv er i sentrum og løftes frem som forklaringsnøkler for diktning, inspirasjon og produksjon (Dam Christensen 2001, Lund 2016:112). Derfor er et av de mest interessante funnene $i$ analysen at personfokuset på Hauge-senteret ikke er dominerende i deres største samling, nemlig boksamlingen. Den kuraterte boksamlingen skaper forbindelser til leseren og tenkeren Hauge. Boksamlingen setter diktningen hans i forbindelse til verden utenfor Ulvik, og gjør den til en del av verdenslyrikken. Når bøkene i utstillingen er redusert til bokrygger og løsrevede litterære referanser koplet sammen gjennom senterets kuraterte tekstutdrag fra Hauges dagbøker, blir diktene, eller mer presist diktningen, til den bærende fortellingen i utstillingen.

I analysen av Hauge-senterets utstilling har jeg vært opptatt av å forfølge hvordan aktørene, både humane og non-humane, oppretter forbindelser. Sammen definerer de hvem Hauge i utstillingen ble. Fra deltakende observasjon i utstillingsrommene har jeg både observert og selv erfart hva publikum gjør, men først og fremst hvordan tingenes plasse- ring, form og mulige interaksjoner påvirker hva som kan gjøres. Ved skille skarpt mellom hvorfor og hvordan - med fokus på hvordan har en rekke aktører blitt introdusert. Det har også ført analysen ut av utstillingsrommet, og vist at stedet Ulvik er sentralt i Hauge-senterets fremstilling av Hauges liv og litteratur.

I møte med tre ulike utstillingsteknologier har jeg vist hvordan interaksjon, materialitet og form virker inn på fortellingene som utstillingen formidler. Utstillingsteknologiene er en del av utstillingens metode; å fortelle med ting, som inkluderer mer enn selve museumsobjektene. Det er ikke overraskende at vinduers utsyn kopler forfatter til stedet utenfor, at et bord kan fortelle om menneskene Hauge omga seg med og som valgte ham, og at bokhyller tematiserer Hauge som leser og litteratur generelt. Men vinduene viser også hvordan landskapet gjennom en todimensjonal, innrammet flate kan skape forestillinger om en verden utenfor Ulvik, mer som en idé enn et konkret sted. Vinduets kvaliteter som åpning og ramme er viktige komponenter for å peke ut fjellene Hauge så og omgivelsene Hauge var i, mens glassets transparens og refleksjon i vinduet dedikert til "Utferdshug" bygger opp under vinduet som et litterært virkemiddel. Det gir rom for kontemplasjon og kan peke innover i menneskesinnet. Bordets flate og form samler besøkende rundt seg og inviterer til bruk. Bordet inviterer til interaksjon med utklippsboken som kan blas i, og skuffer som kan åpnes og lukkes. Hvordan publikum interagerer med installasjonen påvirker hvilke fortellinger de tar med seg fra den. Objektenes plassering i skuffer og på overflate påvirker også objektenes status. Sykehusjournalen blir flettet inn i en større fortelling som setter den i forbindelse til diktning. Skuffens åpne- og lukkefunksjon kan forstås som en sensurert versjon av Hauges sykdomshistorie. Utklippsboken med dikt 
plassert på bordflaten og journalen i skuffen er interessant å sammenligne, fordi spørsmålet om sammenhenger mellom diktning, epledyrking og sykdom skapes i og på bordet. Bordet skal brukes. Ved å stå rundt det, bøye seg over det og åpne det opp finner vi fortellinger om menneskelige forbindelser til omverden fylt av kollegaer, samliv og bekjentskaper. Overraskende er det kanskje at Hauges slekt kun er representert i ett sitat fra Hauges dagbok, i et møbel som skaper assosiasjoner til et av de mest sentrale samlepunktene i et hjem.

Ved å vise hvordan design og utforming har betydning for forståelsen av fortellingene i utstillingsrommene, har jeg insistert på at gjenstandene, med vekt på arrangeringer av dem, har betydning for hvordan jeg leser utstillingene. Metoden og teorien jeg har anvendt, har gjort materialiteten synlig, i senterets arrangeringer av ord, litteratur og gjenstander som blir koplet sammen til en større fortelling. Materialiteten har konsekvenser for hvordan forfatter, verk og forholdet mellom dem kan forstås i utstillingenes virkelighetsbilde. Målet har vært å vise hvordan utstillingens egne kommunikasjonsformer, og måte vi kan interagere med dem på, påvirker fortellingene som formidles. Et resultat av å studere hvordan noe gjøres gir også kunnskap om hva vi kan endre på, om vi vil.

Artikkelen er basert på forskning som del av forskningsprosjektet TRAUM - Transforming Author Museums, finansiert av Norges forskningsråd (prosjektnummer 251225).

\section{Noter}

1. Artikkelen er en bearbeidelse av deler av doktorgradsavhandlingen i museologi Forfattermuseumsfunksjonene. Musealiserte relasjoner mellom liv og litteratur. En studie av
Hamsunsenteret, Bjerkeboek - Sigrid Undsets hjem og Hauge-senteret (Aarbakke 2019).

2. I 2017 telte Hauge-senteret 6915 besøkende, og i 201810360 besøkende (Nynorsk-kultursentrum 2019). Årsaken til at publikumstallene varierer i så stor grad fra et år til et annet, er at Haugesenteret arrangerer poesifestival annethvert år, senest i 2018. Inngangsbillett til senteret er inkludert i festivalbilletten og deler av festivalprogrammet arrangeres på senteret.

3. Litteraturviteren Alison Booth har skrevet om skrivebordet på forfattermuseer (2012). I litteraturviteren Nicola J. Watsons The Author's Effects. On Writer's Home Museums (2020) er forfatteres vinduer og skrivebord trukket frem som særegne attributter. Stefan Bohman et al. har skrevet om August Strindbergs boksamling (2012).

4. For museologiske publikasjoner som anvender aktør-nettverksteori se for eksempel Brenna 2014, Hetherington 1997, Noordegraf 2012.

5. Nasjonalbiblioteket, Hanske privatarkiv, Ms. 83626 Olav H. Hauge: dagbok 1924-1994. Ms.8 3626 27.5-17.10.1968. https://www.nb.no/ nbsok/nb/14f00dcd04313bc370e4aa4e7c4d3989. nbdigital?\#18 (nedlastet 14. mai 2019).

\section{REFERANSER}

Barthes, Roland 1994. "Forfatterens død.” I Knut Stene-Johansen (red.). I tegnets tid. Utvalgte artikler og essays. Oslo: Pax, 49-54.

Berns, Steph 2016. "Considering the glass case: Material encounters between museums, visitors and religious objects." Journal of Material Culture 21:2, 153-168.

Bohman, Stefan, Erik Höök \& Camilla Larsson et al. 2012. Strindberg i Blå tornet. Stockholm: Carlsson.

Booth, Alison 2012. "Houses and things: Literary house museums as collective biography." I Kate Hill (red.). Museums and Biographies. Stories, Objects, Identities. Woodbridge: Boydell Press, 231-246. 
90 Bouquet, Mary 2012. Museums: A Visual Anthropology. London: Berg.

Brenna, Brita 2014. "Nature and texts in glass cases: The vitrine as a tool for textualizing nature." Nordic Journal of Science and Technology Studies 2:1, 46-51.

Dam Christensen, Hans 2001. Forskydningens kunst. Kritiske bidrag til kunsthistoriens historie. København: Multivers.

Damsholt, Tine \& Dorthe Gert Simonsen 2014/2009. "Materialiseringer. Processer, relationer og performativitet." I Tine Damsholt, Dorthe Geert Simonsen \& Camilla Mordhorst (red.). Materialiseringer. Nye perspektiver $p a ̊$ materialitet og kulturanalyse. Aarhus: Aarhus Universitetsforlag, 9-37.

Dewdney, Andrew, David Dibosa \& Victoria Walsh 2013. Post-Critical Museology: Theory and Practice in the Art Museum. London: Routledge.

Hauge-senteret, O. H. 2013. Utstillingsplan basisutstilling 2014.

Henning, Michelle 2006. Museums, Media and Cultural Theory. Maidenhead: Open University Press.

Hetherington, Kevin 1997. "Museum topology and the will to connect." Journal of Material Culture 2:2, 199-218.

Kapstad, Connie Reksten 2007. "Når poesien tar plass. Om Olav H. Hauge, litteratur og festival.” I Nils Gilje \& Torunn Selberg (red.). Kulturelle landskap. Sted, fortelling og materiell kultur. Bergen: Fagbokforlaget, 156-178.

Latour, Bruno 2005. Reassembling the Social: An Introduction to Actor-Network-Theory. Oxford: Oxford University Press.

Law, John 1999. "After ANT: Complexity, naming and topology" Sociological Review 47:1, 1-14.

Lund, Niels. D. 2016. ”Litteraturen og forfatteren på museum. Traditionsformidling udfordret af den stigende musealisering." Nordisk Museologi 1, 101-120.

Mol, Annemarie 2010. "Actor-network theory: Sensitive terms and enduring tensions." Kölner Zeitschrift für Soziologie und Sozialpsychologie 50: 253-269.

Noordegraf, Julia 2012. Strategies of Display: Museum Presentation in Nineteenth- and TwentiethCentury Visual Culture. Rotterdam: nai010 publishers.

Nynorsk-kultursentrum 2019. Årsmelding og rekneskap. https://www.haugesenteret.no/ohh/ no/om_oss/arsmeldingar/ (nedlastet 31. oktober 2019).

Pripp, Oscar \& Magnus Öhlander 2011/1999.

"Observation." I Lars Kaijser \& Magnus Öhlander (red.). Etnologiskt fältarbete. Lund: Studenterlitteratur, 65-84.

Watson, Nicola J. 2020. The Author's Effects. On Writer's House Museums. Oxford, New York: Oxford University Press.

Åmås, Knut Olav 2004. Mitt liv var draum. Ein biografi om Olav H. Hauge. Oslo: Samlaget.

Aarbakke, Thea 2019. Forfattermuseumsfunksjonene. Musealiserte relasjoner mellom liv og litteratur. En studie av Hamsunsenteret, Bjerkebok - Sigrid Undsets hjem og Hauge-senteret. Oslo: 07Media.

Thea Aarbakke, ph.d. Prosjektkoordinator Anno Kvinnemuseet. thea.aarbakke@annomuseum.no

\section{Anno Kvinnemuseet Kongsvinger festning 2 $\mathrm{N}$-2213 Kongsvinger, Norge}

